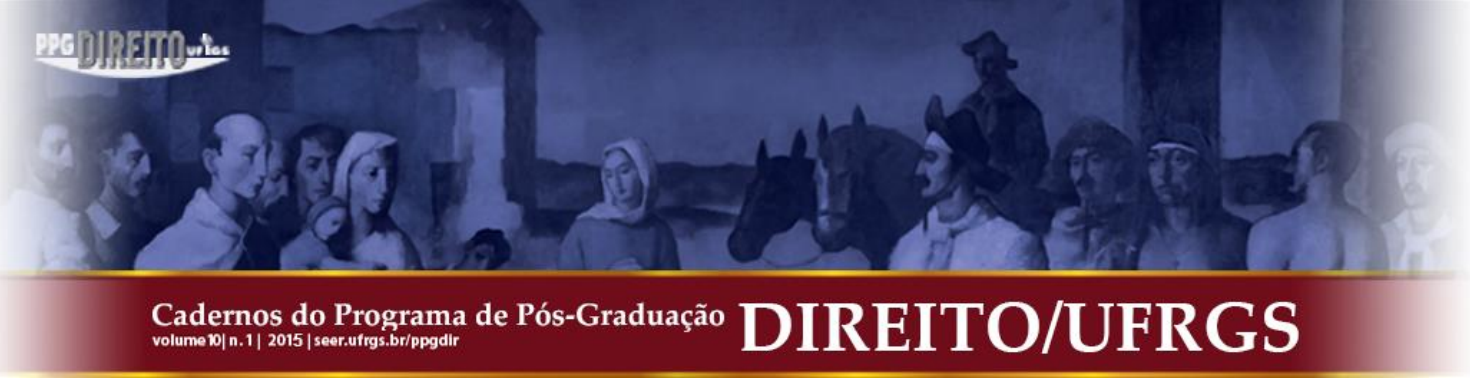

\title{
DA APLICABILIDADE DA JUSTIÇA RESTAURATIVA À VIOLÊNCIA MORAL EM FUNÇÃO DO GÊNERO
}

\author{
APPLICABILITY OF RESTORATIVE JUSTICE TO MORAL VIOLENCE BASED IN \\ GENDER
}

\begin{abstract}
RESUMO: A presente pesquisa teve por fim verificar se o denominado "assédio moral" praticado contra vítima do gênero feminino encontra proteção no ordenamento penal brasileiro. Diante da constatação de uma lacuna legislativa, procurou-se avaliar se o sistema penal poderia oferecer uma resposta ao problema e, concluindo que o mesmo não é capaz de cumprir suas funções declaradas, estudou-se os postulados da Justiça Restaurativa, que se mostrou uma via legítima e adequada para sanar os conflitos intersubjetivos intrafamiliares.
\end{abstract}

PAlavras-Chave: Assédio Moral. Lei Maria da Penha. Justiça Restaurativa.

SUMÁRIO: Introdução. 1. Assédio moral. 2. Ineficácia das políticas institucionais punitivas contra violência de gênero. 3. Postulados da justiça restaurativa. Conclusões. Referências.
Andressa Loli Bazo* Alexandre Ribas de Paulo**

\begin{abstract}
The purpose of this research was to verify if the socalled "moral harassment" practiced mainly against female victims finds protection in the Brazilian criminal justice system. Faced with the existence of a legislative gap, this research tried to assess whether or not the criminal justice system could offer a real answer to the problem, and, concluding that it is not able to fulfill its declared functions, it was studied the postulates of Restorative justice, which proved to be a proper and legitimate way to remedy the intersubjective conflicts within the families.
\end{abstract}

KEYWORDS: Moral Harassment. Maria da Penha Statute. Restorative Justice.

\section{INTRODUÇÃO}

O presente trabalho tem como objetivo compreender algumas características da denominada violência moral praticada em decorrência do gênero no ambiente intrafamiliar e, diante da sua não previsão específica como tipo no ordenamento jurídico-penal, desenvolver uma ideia de tutela jurisdicional por intermédio dos postulados da Justiça Restaurativa, atualmente preconizadas na Resolução n⿳0 125/2010, do Conselho Nacional de Justiça.

Em um primeiro momento é feita uma breve análise daquilo que os juristas convencionaram denominar de assédio moral e identificá-lo como uma forma de tratamento desumano, expressamente vedado pela Constituição Federal brasileira no seu art. 5ํㅜ inciso III. Em seguida destaca-se o assédio moral na seara doméstica, na unidade familiar ou em qualquer relação de afeto ou intimidade. Nesse plano, entra em questionamento o tratamento

\footnotetext{
* Mestranda em Direito Penal, Medicina Forense e Criminologia pela Faculdade de Direito da Universidade de São Paulo (FDUSP).

** Professor Adjunto do Departamento de Direito Privado e Processual da Universidade Estadual de Maringá. 


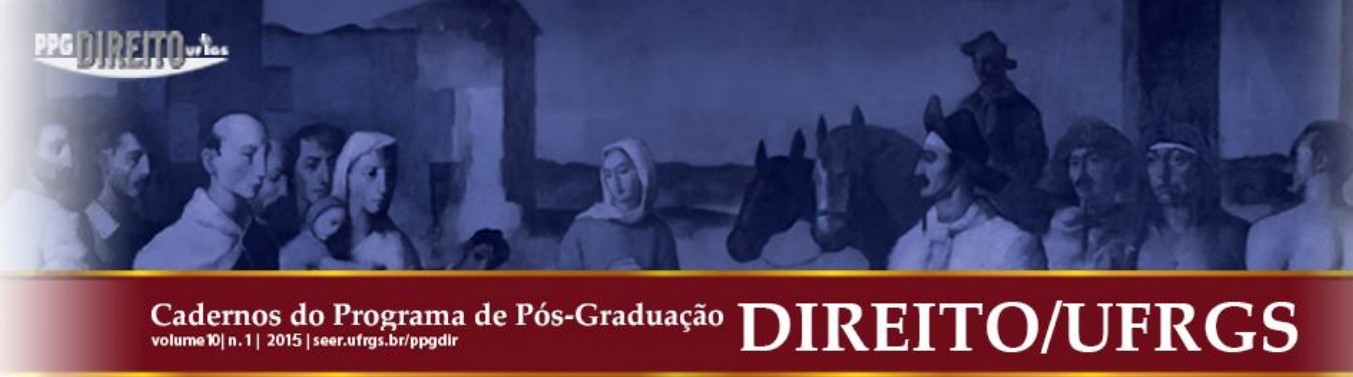

jurídico especial com a entrada em vigor do microssistema de caráter repressivo, preventivo e assistencial conhecido como Lei Maria da Penha (Lei 11.340/2006).

Salienta-se que, embora a complexidade do conceito de gênero suscite inúmeras discussões, o objeto deste artigo não compreende as teorias feministas que se prestam a revelar seus desdobramentos, mas especificamente as definições previstas em lei, mormente porque na seara penal vigora o princípio da legalidade.

Por derradeiro, considerando as carências do Sistema Penal brasileiro no que toca à resolução dos conflitos entre as partes humanas, apresenta-se uma comparação entre paradigma retributivo e paradigma restaurativo, que oferece uma alternativa ao tradicional modelo de solução de conflitos e um novo meio de acesso à justiça, verificando-se sua capacidade de satisfazer as necessidades da vítima, do ofensor e da comunidade, com especial atenção à violência moral perpetuada no ambiente familiar.

Para a elaboração da pesquisa, foi utilizado como marco teórico as acepções de Thomas Kuhn no que diz respeito à mudança de paradigma científico, tendo como metodologia a técnica de levantamento e análise da bibliografia e legislação existente sobre o tema posto, priorizando-se o método indutivo, com vistas a compreender, mediante um olhar teórico e crítico, se a Justiça Restaurativa no âmbito penal brasileiro é realmente uma via adequada para a efetiva solução do conflito intersubjetivo que envolve o assédio moral no âmbito intrafamiliar.

\section{ASSÉDIO MORAL}

Um dos temas mais profícuos no estudo das ciências diz respeito à violência, que em uma de suas acepções no âmbito das ciências sociais pode ser compreendida como "una relación de fuerza destinada a someter o a obligar o outro." (MUCHEMBLED, 2010, p. 17). Sob o prisma jurídico-penal brasileiro, o resultado da violência leva a lesões ao ser humano, que costumam ser classificadas como física e psicológica. Ambas se manifestam em lesões corporais, de tal forma que a primeira geralmente é reconhecida por alterações anatômicas e/ou funcionais em órgãos ou tecidos e a segunda por transtornos de ordem psíquica. Nas palavras do médico legista Genival Veloso de França (2004, p. 148): “lesão é toda alteração do equilíbrio biopsicossocial." 


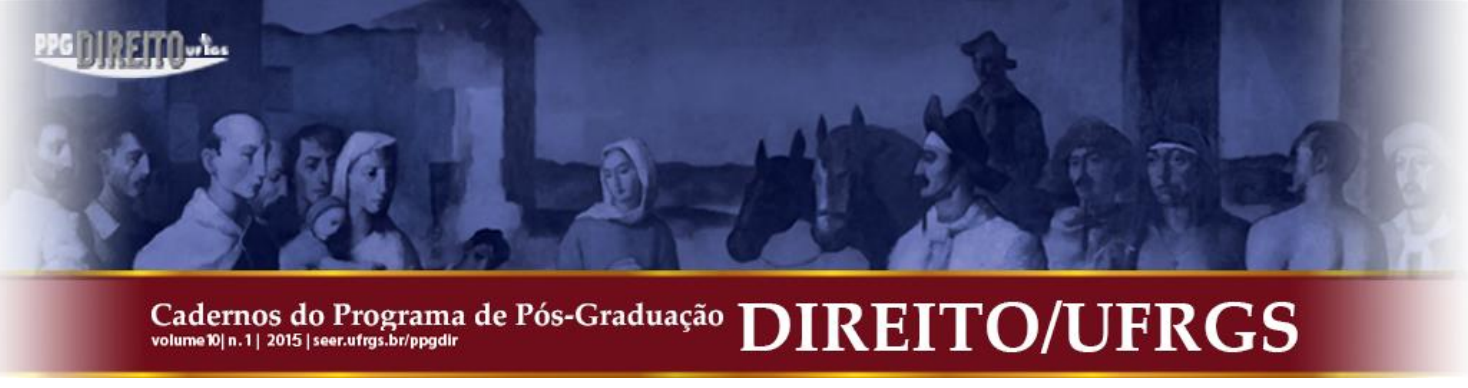

A despeito das classificações já destacadas, há alguns anos um tipo de relação de força intersubjetiva, denominada "assédio moral", encontrou sua gênese discursiva nas relações pertinentes ao Direito do Trabalho, começando a ganhar seus delineamentos teóricos pelos juristas, na tentativa de torná-lo, também, um ilícito penal. Esse tipo de violência, a princípio, se manifestaria de forma diferente às tradicionais agressões físicas que interessam à traumatologia e não seriam, por outro lado, condutas caracterizadas como crimes contra a honra.

Os danos causados pelo assédio moral também são encontradas, amiúde, no ambiente doméstico, caracterizado por práticas indiretas e subliminares, consistentes numa manipulação perversa por parte do agressor, que se utiliza de técnicas de desestabilização habituais, como alusões malévolas, humilhações, intimidações, monopolização da percepção, bem como discriminação do espaço físico, minando despoticamente a autoconfiança da vítima. Segundo Marie-France Hirigoyen (2007, p. 11), psiquiatra, psicanalista, psicoterapeuta familiar e professora da Universidade de Paris, com formação em vitimologia: “essas agressões têm origem em um processo inconsciente de destruição psicológica, constituído de maquinações hostis, evidentes ou ocultos, de um ou de vários indivíduos, sobre um indivíduo determinado."

Trata-se de uma violência simbólica que, silenciosamente, corrói as potencialidades da vítima. Pierre Bourdieu e Jean-Claude Passeron (1982, p. 19) afirmam que "todo poder que chega a impor significações e impô-las como legítimas, dissimulando as relações de força que estão na base de sua força, acrescenta sua própria força, isto é, propriamente simbólica, a essas relações de força."

O resultado degradante seria auferido pela frequência, continuidade, permanência ou reiteração com que o agressor rebaixaria o outro, atingindo, por vezes, a própria identidade da vítima, de forma a extrair toda sua individualidade. Por derradeiro, verifica-se que a magnitude do injusto do assédio moral seria muito maior do que a de uma mera perturbação da tranquilidade e do sossego, gerando efeitos perniciosos no cotidiano da pessoa assediada. Não se pode considerar assédio moral mero descontrole comportamental isolado, vez que conflitos pontuais e destemperos ocasionais fazem parte das relações interpessoais. A violência, no assédio moral, é empregada com o fim de explorar, oprimir e dominar a ponto de impedir o exercício da manifestação da vontade e da autonomia da pessoa visada, não podendo ser confundida com padrões cotidianos de agressão verbal. 


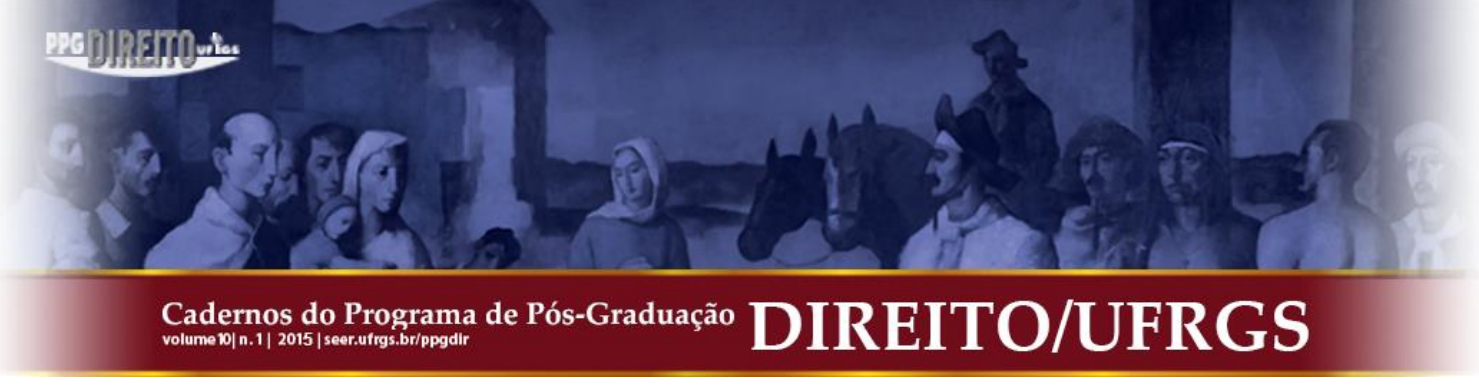

Embora o sentimento de humilhação, que acompanha toda lesão penalmente relevante à integridade moral, costuma aparecer associado ao conceito de honra, esta não se confunde com aquela. O bem jurídico protegido pelos delitos contra a honra é a pretensão ao respeito da própria personalidade, cujo valor é insuscetível de apreciação. A doutrina costuma diferenciar honra subjetiva (bem jurídico lesionado pelo delito de injúria), que se refere à autoestima, de honra objetiva (bem jurídico lesionado pelos delitos de calúnia e difamação), entendida como a reputação do indivíduo perante a sociedade, relativamente a seus atributos culturais, intelectuais, físicos, éticos (BITENCOURT, 2010, p. 315). A definição de honra subjetiva, que aborda os sentimentos da própria honorabilidade ou valor social e a consciência da respeitabilidade pessoal, se aproxima em grande parte do conceito de integridade moral, vez que ambas são expressões diretas da dignidade humana. Entretanto, as agressões à integridade moral exigem reiteração ou habitualidade. De outra parte, os ataques à integridade moral não dependem das características particulares da vítima, como normalmente ocorre com as agressões à honra objetiva.

A integridade moral também não se identifica com a integridade corporal nem com a saúde física ou psíquica, mas, com mais razão, com a inviolabilidade anímica, porque o assédio moral não resulta em transtorno mental ${ }^{1}$, mesmo que cause uma desordem emocional de dimensões consideráveis. Nesse sentido, a pessoa pode apresentar traços de caráter de determinada patologia, como a reexperimentação de eventos traumáticos, a evitação sistemática de estímulos associados ao trauma ou o embotamento da capacidade de resposta, sem ser portadora da mesma.

Dessa forma, o assédio moral pressupõe um sofrimento subjetivo que só pode ser mensurado por escalas culturais, segundo um juízo de valor moral. Diferentemente da psicopatologia, que requer um diagnóstico nos termos da Classificação Internacional de Doenças (CID 10) ou do Manual Diagnóstico e Estatístico de Transtornos Mentais (DSM IV), o assédio moral não seria, necessariamente, detectado pela perícia médica. Ao prescindir de um resultado palpável, a violência moral configura um devalor na ação mesma do assediador.

\footnotetext{
${ }^{1}$ Por transtorno mental, entende-se “[...] a existência de uma síndrome ou padrão psicológico associado ao sofrimento (sintoma que causa dificuldades), à incapacitação (deterioração de uma ou várias áreas importantes de funcionamento psíquico) ou a um elevado risco de morte, dor, incapacitação, ou a importante perda de liberdade. $\mathrm{O}$ dano psíquico distingue-se do sofrimento por inserir em seu conceito a noção de lesão às faculdades mentais, incluindo o afetivo, enquanto que o dano moral não implica conformação patológica. [...] Assim, o sofrimento enquanto expressão de uma lesão aos sentimentos da pessoa, também chega a limitar o gozo da plena saúde inerente à personalidade e, por isso, se constitui em uma espécie de dano, no caso do dano moral." (ROVINSKI, 2004, p. 64).
} 


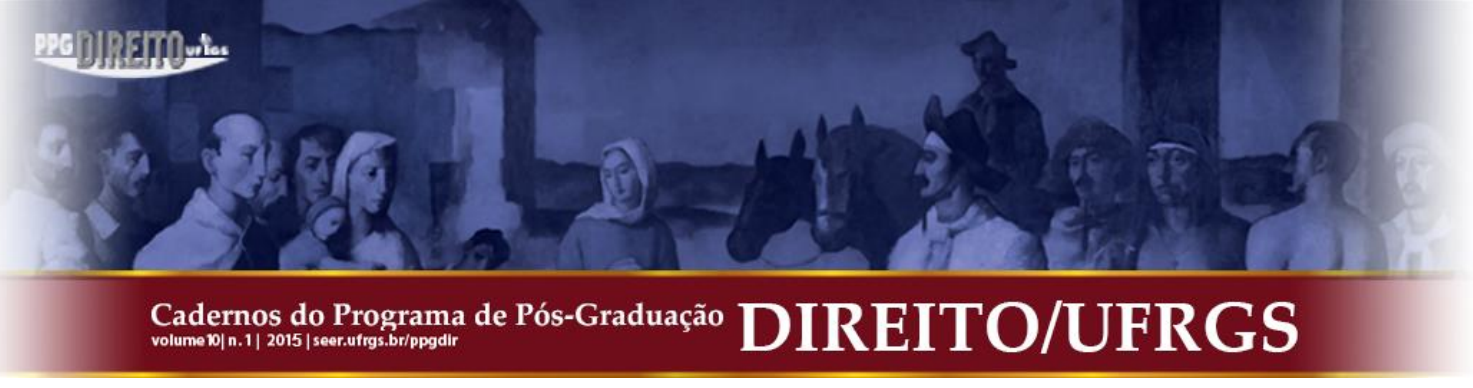

Com isso, verifica-se que o assédio moral não é abarcado pelo delito de lesões corporais tipificado no artigo 129, do Código Penal. Este, por sua vez, torna ilícito o comportamento de "ofender a integridade corporal ou a saúde de outrem", de forma a compreender a alteração anatômica ou funcional, interna ou externa, do corpo humano e a alteração de funções fisiológicas do organismo ou perturbação psíquica, respectivamente. Assim sendo, não basta a exposição a perigo do bem jurídico tutelado, posto que a plena realização do tipo de lesões corporais é condicionada à superveniência de um resultado concreto no qual se manifeste a efetiva ofensa materialmente aferível (artigos 158 e 168, ambos do Código de Processo Penal).

Por outro lado, o artigo 5o, inciso III, da Constituição Federal institui que: "ninguém será submetido à tortura nem a tratamento desumano ou degradante." Nessa perspectiva, embora não exista um tipo específico para o controle das condutas que seriam compreendidas como assédio moral, este degrada o ser humano em sua consciência como tal, devendo ser criada uma via que possibilite tutela jurisdicional para proteção da sua integridade moral, pois como diz o inciso XXXV, do mesmo artigo 5ํㅜ, da Constituição: "a lei não excluirá da apreciação do Poder Judiciário lesão ou ameaça a direito.”

Assim como as lesões corporais, o assédio moral também pode se manifestar contra a mulher por razões de gênero. Para tanto, a Lei 11.340/2006 (Lei Maria da Penha) preconiza três formas de atuação a serem aplicadas simultaneamente, quais sejam, punitiva, protetiva e psicossocial. Esse diploma conta com um arsenal discursivo que intenta consubstanciar uma rede social de apoio articulada com o juizado de violência doméstica e familiar contra a mulher, contemplando um amplo catálogo de medidas de caráter extrapenal destinadas a prevenir a violência de maneira integral, prestando informações, orientações e condições de segurança para a vítima e seus dependentes.

Apesar de verificarem-se medidas de: a) longo prazo tais como a promoção de pesquisas e estatísticas para determinar as causas da violência doméstica (art. $8^{\circ}$, II), controle da publicidade sexista (art. $\left.8^{\circ}, \mathrm{III}\right)$, promoção de campanhas educativas dirigidas às escolas e à sociedade (art. $\left.8^{\circ}, \mathrm{IV}\right)$; b) medidas de curto prazo ou de realização imediata destinadas a facilitar o acesso a recursos governamentais e a mobilidade da mulher em situação de violência doméstica, como o cadastro nos programas assistenciais governamentais (art. $9^{\circ}$, $\S 1^{\circ}$ ), remoção prioritária no serviço público (art. $\left.9^{\circ}, \S 2^{\circ}, \mathrm{I}\right)$, fixação de alimentos provisionais (art. 22, V) e c) medidas de proteção e contenção de riscos, como o atendimento 
O sistema penal não apenas é estruturalmente incapaz de oferecer alguma proteção à mulher, como a única resposta que está capacitado a acionar - o castigo - é desigualmente distribuído e não cumpre as funções intimidatória e simbólica que se lhe atribui. Em suma, tentar a domesticação da violência com a repressão implica exercer, sobre um controle masculino violento de condutas, um controle estatal tão ou mais violento; implica uma duplicação do controle, da dor e da violência inútil.

Em seguida, a mesma autora (Ibid., p. 124) questiona a validade prática da vitimização feminina - caracterizada tradicionalmente como merecedora da proteção masculina, seja do homem ou do Estado - como mecanismo de luta dentro da seara penal:

Trata-se, portanto, de deslocar o leme da luta jurídica e de ressaltar a importância da construção de um espaço público politizado pelas mulheres como sujeitos pela via da positividade dos Direitos, particularmente do Direito Constitucional (recoberto e sustentado, obviamente, pelo plano das Declarações internacionais dos direitos da mulher) e conducente a uma construção positiva (e não defensiva) da cidadania.

O discurso jurídico, embora aparentemente atraente por prometer proteção a bens juridicamente relevantes e buscar - discursivamente - a reeducação do infrator, é incapaz de resolver a raiz dos conflitos intersubjetivos. Nas palavras de Alessandro Baratta (2011, p. 155): “[...] a ciência jurídica formal não se revela em condições de refletir e de superar a própria ideologia negativa. A crítica e a superação desta não provêm do interior, mas do exterior dela [...]." Portanto, a dogmática penal segue um paradigma monista incapaz de oferecer uma solução adequada ao conflito, vez que se apresenta como uma ciência metalinguística, isto é, que se vale do discurso pelo discurso, desarticulada da realidade e dos escopos mais nobres que poderiam ser extraídos da exegese do artigo 5을 inciso XXXV, da Constituição Federal.

Por outro lado, o recurso à via sócio-terapêutico se mostraria mais adequada para desativar o mecanismo de alienação que impera numa relação intrafamiliar abusiva. Acrescente-se a isto a desconfiança no Estado frente a serviços médicos, sociais e organizações de mulheres, que, à margem da família, é o grupo com uma valoração mais positiva na luta contra a violência de gênero e no apoio às vítimas. Por conseguinte, adotar o instrumento repressor como via primordial de erradicação da violência de gênero não é uma solução ajustada para a sociedade e tampouco para os envolvidos no conflito.

Concebendo a distinção entre duas categorias de direito humanos, os direitos-barreira ou de proteção e os direitos-à-obtenção, Álvaro Pires (2004, p. 55) esclarece: “Os primeiros visam garantir uma zona de autonomia individual, limitando a ingerência do Estado (e de 


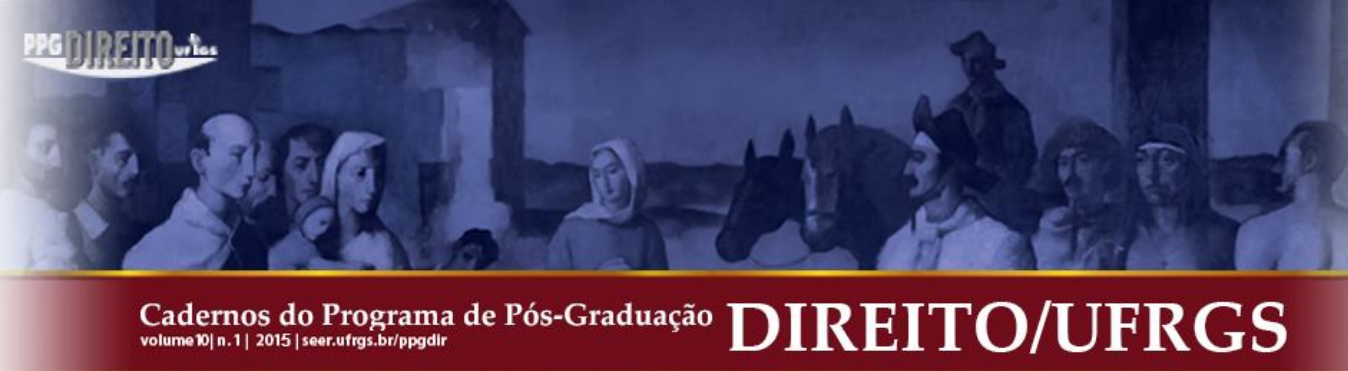

particulares) na vida (privada) dos indivíduos. Os últimos visam promover o bem-estar social do autor que os reivindica." Sob o prisma da racionalidade penal moderna, "direitos de proteção" conduzem necessariamente a um direito de obter uma pena, ignorando qualquer outra forma de defesa contra a ingerência. Contudo, sob a perspectiva dos direitos verdadeiramente humanos, àqueles "direitos de proteção" correspondem bens positivos, aptos a produzir por si mesmo e imediatamente o bem estar (assistência médica), favorecendo a emancipação do indivíduo.

É um bem pragmático intrinsecamente associado ao direito reivindicado, pois o bem é o direito e o direito é um bem, a ponto de não se poder separar uma coisa da outra: é o direito mesmo que é pedido [...] É um bem cujo efeito para a realização do que é pedido não é hipotético, longínquo, nem mediado pelo mal ou exclusivamente fundado em saberes (e sobretudo em saberes contestados). (PIRES, Op. cit., p. $56 / 57)$.

Por derradeiro, enfatiza-se a necessidade de romper com uma história de cultura autoritária, sexista e discriminatória transgeracional que adota um modelo patriarcal de estratificação social, bem como rejeitar estereótipos e desconstruir a assimetria de gênero, rompendo com padrões culturais enraizados no pensamento jurídico, eventos estes epidemiológicos. Sob este enfoque, deve-se questionar a dinâmica da negação, minimização, justificação da violência e a complacência social e institucional para com ela, primando-se pela "reconstrução de parâmetros igualitários de direito, numa cultura secularmente excludente" (CAMPOS, A., 2010, p. 39) cujo componente estrutural reside na subordinação econômica, pessoal e afetiva.

Defende-se, portanto, o desvelamento de condutas tratadas anteriormente como verdadeiros tabus através de campanhas de conscientização, que conferem transparência e visibilidade ao fenômeno da violência doméstica contra a mulher, bem como a fomentação de políticas assistenciais e reparadoras às vítimas aliadas à potencialização dos atributos positivos do agressor (ressignificação do ser homem). Dar visibilidade à violência insidiosa que tem lugar com o assédio moral não significa tipificá-lo, isto é, relegitimar o monopólio estatal da violência pelo Direito Penal. Nesse sentido, Vera Regina Pereira de Andrade (Op. cit., p. 118) enfatiza: "Redimensionar um problema e reconstruir um problema privado como um problema público ou social não significa que o melhor meio de responder a ele seja convertê-lo, quase que automaticamente, em um problema penal, ou seja, em um crime." 


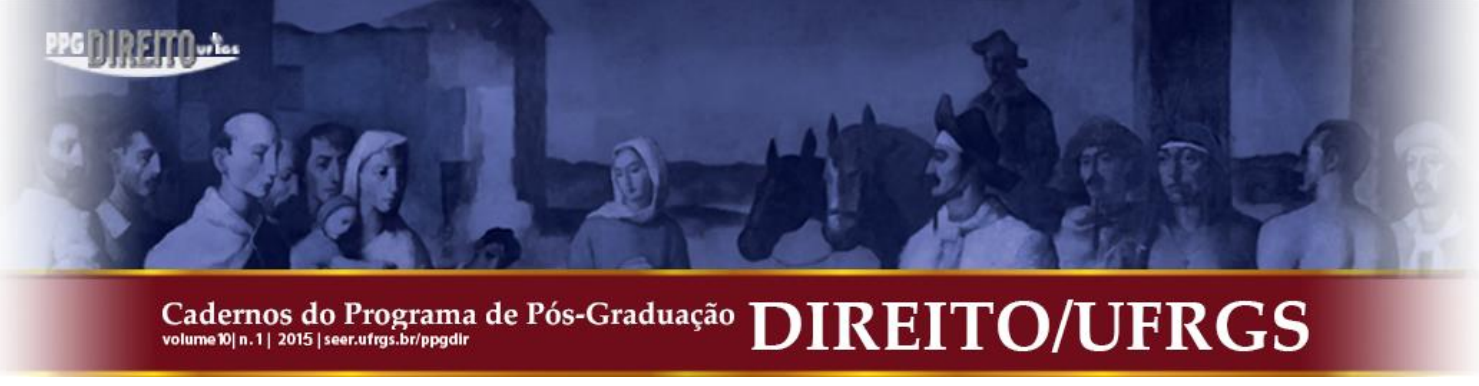

Importa esclarecer que o conceito de violência trazido pela Lei n. 11.340/06 difere daquele pertencente ao Direito Penal. A Lei Maria da Penha se vale do sentido sociológico de violência, sob uma perspectiva de política criminal. Muitas das condutas descritas como violência de gênero na Lei 11.340 não constituem tipos penais (crimes ou contravenções). Nestes casos, não deveria haver intervenção no âmbito penal.

Dessa forma, o ataque específico ao bem jurídico integridade moral não é disciplinado pelo Código Penal e eventual referência geográfica que porventura pudesse vir a ser acrescentada pela Lei Maria da Penha não passaria de um elemento acidental do assédio moral. Gisele Mendes de Carvalho (2010, p. 409), nessa perspectiva, argumenta: "O que ocorre é que o assédio moral tende a ser favorecido pela sua ocorrência em determinados âmbitos, onde por vezes resulta mais fácil para o assediador subjugar a vontade da vítima, prevalecendo-se de relações pessoais [...]".

A despeito da importância do bem jurídico violado pelo assédio moral, não se pode negar que a demanda pela criminalização do mesmo, apesar de bem intencionada, é mal construída, vez que orientada pela racionalidade penal moderna na direção da distribuição de bens negativos, sem outro ganho jurídico, moral ou social concreto e imediato que produzir mais sofrimento (Cf. PIRES, Op. cit., p. 59). Ainda, no que tange à violência de gênero, a lei atua em um contexto estrutural e político adverso, exercendo escassamente seu papel transformador.

Consoante Carmen Hein de Campos (2008, p. 244): “apesar do discutível recurso ao Direito Penal, reconhece-se a idoneidade de uma política criminal de gênero quando ela estabelece uma mínima intervenção punitiva e uma máxima intervenção social.” Por outro lado, salienta Maria Lúcia Karam (2006, p. 6):

\footnotetext{
A repressão penal, qualquer que seja sua direção, em nada pode contribuir para o reconhecimento e garantia de direitos fundamentais, tampouco podendo trazer qualquer contribuição para a superação de preconceitos ou discriminações, até porque preconceitos e discriminações estão na base da própria ideia de punição exemplificativa, que informa e sustenta o sistema penal.
}

Por fim, observa-se que, apesar de a Lei Maria da Penha não criar tipo penal, inovou nas providências processuais penais e aprimorou uma agravante (artigo 61, inciso " $\mathrm{f}$ ", do Código Penal) com o fim de combater a violência de gênero. Ocorre que tais medidas, ao contrário das campanhas de conscientização e políticas públicas de empoderamento da mulher, não lograram o êxito esperado, mas, ao revés, deixaram explícito que o Direito Penal 


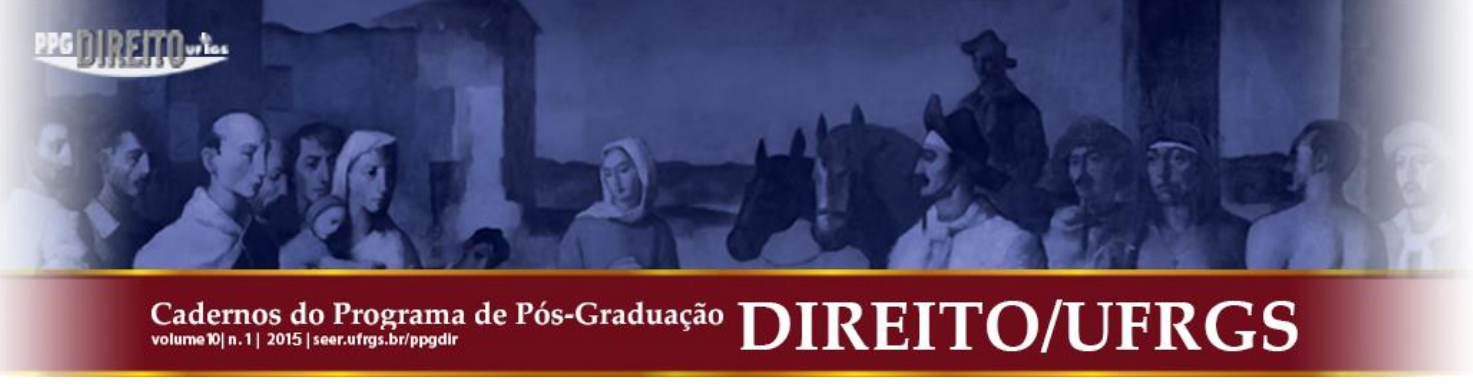

não sustenta mais a posição de ultima ratio, não logrando êxito tampouco em seu papel simbólico de controle e pacificação sociais. De tal forma, não seria viável elevar o denominado "assédio moral" no âmbito intrafamiliar à categoria de infração penal, vez que a criminalização de complexos problemas sociais é incapaz de atingir o fim de educar a moral societária.

Entretanto, analisado seu potencial destruidor das relações afetivas e da personalidade da vítima, necessário se faz um tratamento da dor infligida, não necessariamente no sentido de compensação econômica, mas, mormente, no restabelecimento do amor próprio e capacidade de relacionar-se de forma saudável e prazerosa com o outro.

\title{
3 POSTULADOS DA JUSTIÇA RESTAURATIVA
}

Enquanto a Justiça Retributiva se atém a um conceito jurídico-normativo de crime (fato típico, ilícito e culpável), a Justiça Restaurativa se baseia num conceito realístico de crime (ato que traumatiza a vítima, causando-lhe danos). Nesse sentido, Guita Grin Debert e Maria Filomena Gregori (2008) esclarecem que a concepção de crime não se confunde com a de violência:

\begin{abstract}
Crime implica a tipificação de abusos, a definição das circunstâncias envolvidas nos conflitos e a resolução destes no plano jurídico. Violência, termo aberto aos contenciosos teóricos e às disputas de significado, implica o reconhecimento social (não apenas legal) de que certos atos constituem abuso, o que exige decifrar dinâmicas conflitivas que supõem processos interativos atravessados por posições de poder desiguais entre os envolvidos. As violências evocam uma dimensão relacional que, segundo Foucault, estão longe de serem resolvidas pela esfera jurídica, pois tal instância, mesmo tendo como objetivo a justiça para todos, cria, produz e reproduz desigualdades.
\end{abstract}

Tendo em vista que o assédio moral não se trata de um tipo penal, ou seja, de um crime, mas sim de uma violência, então a Justiça Restaurativa se apresenta como um âmbito privilegiado para tratar do conflito, sem esbarrar em problemas com as teorias penais estatais, isto é, sem negar ao Poder Judiciário sua função jurisdicional prevista no artigo 5ํㅡㄹ da Constituição Federal.

Recomendada pela Organização das Nações Unidas como um novo modelo de justiça (Resoluções 1999/26, 2000/14 e 2002/12), a Justiça Restaurativa, pautada na multidimensionalidade humana (ausência de rótulos), tem por objetivo primordial a restauração das relações sociais conflitivas, por meio da responsabilização dos envolvidos e 


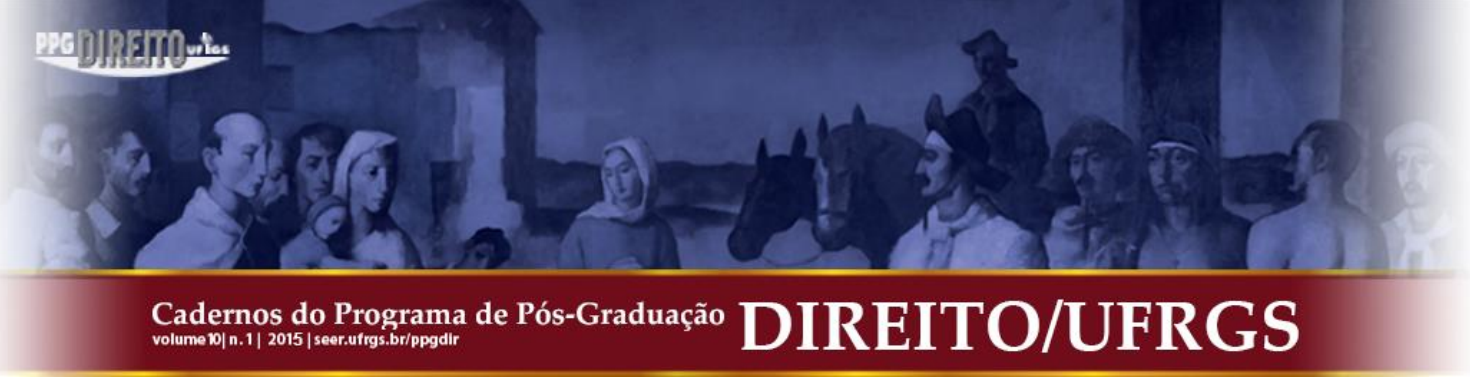

reparação dos danos ocorridos em uma determinada relação segundo uma ética comunitária e emancipatória, promovendo uma cultura de paz. Nesse sentido, a Justiça Restaurativa, sob uma perspectiva kuhniana ${ }^{6}$, se apresenta como um novo paradigma (persuasivo), ao passo que o modelo formal de Justiça Criminal, dito retributivo (dissuasório e deficientemente ressocializador) representa o paradigma em crise. Nessa trilha, Renato Sócrates Gomes Pinto (2005, p. 22) explica que:

\begin{abstract}
O modelo restaurativo baseia-se em valores, procedimentos e resultados definidos, mas pressupõe a concordância de ambas as partes (réu e vítima), concordância essa que pode ser revogada unilateralmente, sendo que os acordos devem ser razoáveis e as obrigações propostas devem atender ao princípio da proporcionalidade. A aceitação do programa não deve, em nenhuma hipótese, ser usada como indício ou prova no processo penal, seja o original seja em um outro.
\end{abstract}

A Justiça Restaurativa idealiza uma mudança do paradigma de confrontação Estadodelinquente para a tríade infrator-vítima-comunidade. O procedimento restaurativo promove o encontro voluntário e consensual, relativamente informal, das pessoas envolvidas em situação de conflito ou violência (vítima, ofensor, familiares, amigos e comunidade) para, orientados por um coordenador ou facilitador, abordarem ativamente o problema e construírem soluções, “[...] podendo ser utilizadas técnicas de mediação, conciliação e transação para se alcançar o resultado restaurativo [...].” (PINTO, Op. cit., p. 20). Dessa forma, não sendo vinculada pelos rigores das normas processuais e substanciais pertinentes à persecutio criminis, a Justiça Restaurativa permite aos indivíduos empoderarem-se concretamente de seus conflitos e tornarem-se os sujeitos principais na busca da solução dos mesmos, ou seja, preencher os vazios não abordados pelo processo penal.

O procedimento restaurativo, preconizado especialmente na Resolução $n^{-0}$ 2002/12, do Conselho Econômico e Social da Organização das Nações Unidas, desenvolve-se mediante uma recontextualização construtiva do conflito, sendo dividido em três etapas. O pré-círculo consiste na primeira fase e sucede por meio de vários encontros entre o coordenador, autor, receptor e comunidade para esclarecerem o fato, as consequências, os participantes convidados, as próximas etapas do procedimento e a vontade de participar delas, de forma a estabelecer um vínculo de confiança entre os participantes e o coordenador. É esclarecido que o círculo não serve para apontar culpados e definir punições - a ideia é voltar-se para o futuro ao invés de concentrar-se no passado -, mas, pelo contrário, só acontece quando já se conhece

\footnotetext{
${ }^{6}$ Paradigma significa "realizações científicas universalmente reconhecidas que, durante algum tempo, fornecem problemas e soluções modelares para uma comunidade de praticantes de uma ciência." (KUHN, 2003, p. 13). 


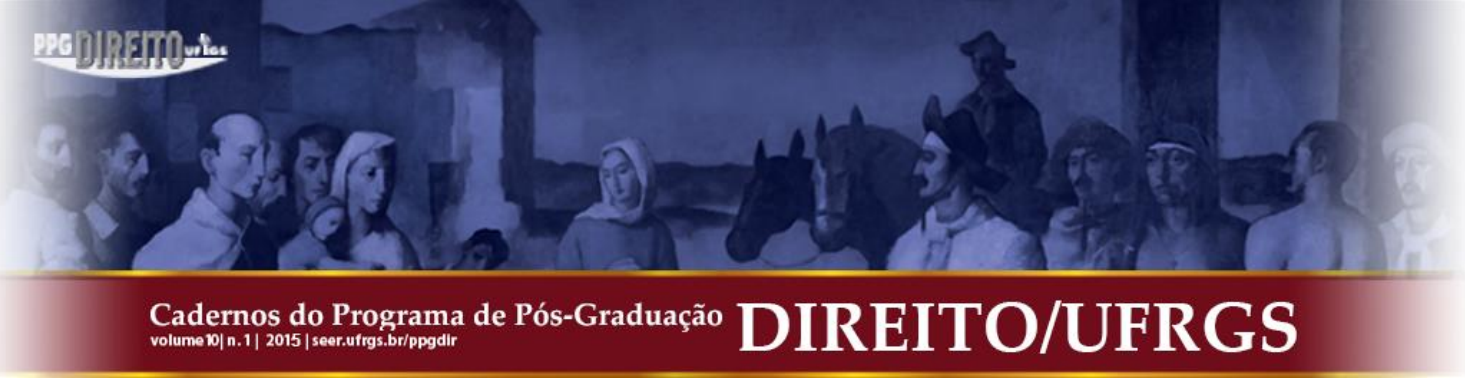

o autor e o fato. A ênfase reside, portanto, nas relações pessoais prejudicadas, suas consequências e danos.

No círculo restaurativo ocorre o relato dos fatos e de suas consequências materiais e psicológicas para os envolvidos, a expressão das necessidades dos participantes em relação ao conflito e a discussão das possibilidades e formas de responder a elas. Essa segunda etapa divide-se em três fases, quais sejam, compreensão mútua entre o autor e o receptor do fato, com foco nas necessidades atuais em relação ao fato ocorrido; autorresponsabilidade, voltada para as necessidades ao tempo do fato; e acordo, com foco em atender as necessidades individuais e coletivas das partes e a reintegração social ${ }^{7}$ da vítima e do infrator.

Este momento possibilita aos presentes definir e propor ações concretas para transformarem o conflito, firmando um compromisso com prazo claro e possível para a realização dessas ações mediante a recapitulação das necessidades não atendidas manifestadas pelos participantes. No plano extrajudicial, o acordo é acompanhado pela própria comunidade, estimulando a emancipação das comunidades plurais brasileiras; no âmbito judicial, este será apresentado ao juiz como forma alternativa de cumprimento da sentença.

Finalmente, o pós-círculo é um encontro de expressão e avaliação entre os participantes do círculo restaurativo e aqueles que colaboraram na realização das ações do acordo para verificação do nível de satisfação. O procedimento pode ser encerrado, se cumprido o acordo, ou novas alternativas serão sugeridas para o prosseguimento.

A expressão círculo exprime tanto a disposição espacial das pessoas no encontro restaurativo quanto os princípios da igualdade e horizontalidade objetivados nesses encontros, pois todos que participam do círculo (envolvidos e interessados), independente de sua condição ou função, encontram-se em pé de igualdade. Assim, todos têm oportunidade de se expressarem em busca de ações que possibilitem prevenir a violência e lidar com suas implicações, evitando sua propagação. Visando a harmonização da comunidade, o círculo restaurativo valoriza a autonomia das pessoas e prima pelo diálogo e acolhimento entre os participantes, favorecido pela presença de pessoas do relacionamento afetivo e comunitário dos envolvidos que, além de prestarem apoio moral e emocional, criam um clima favorável ao

\footnotetext{
${ }^{7}$ Inserida num universo de discurso diferente, a reintegração social adquire um novo significado. Nas palavras de Thomas Kuhn (op. cit., p. 253): “A experiência da conversão assemelha-se a uma mudança de perspectiva. Num determinado momento do processo de aprendizagem da tradução, o indivíduo descobre que ocorreu a transição, que ele deslizou para a nova linguagem sem ter tomado qualquer decisão a esse respeito.” 


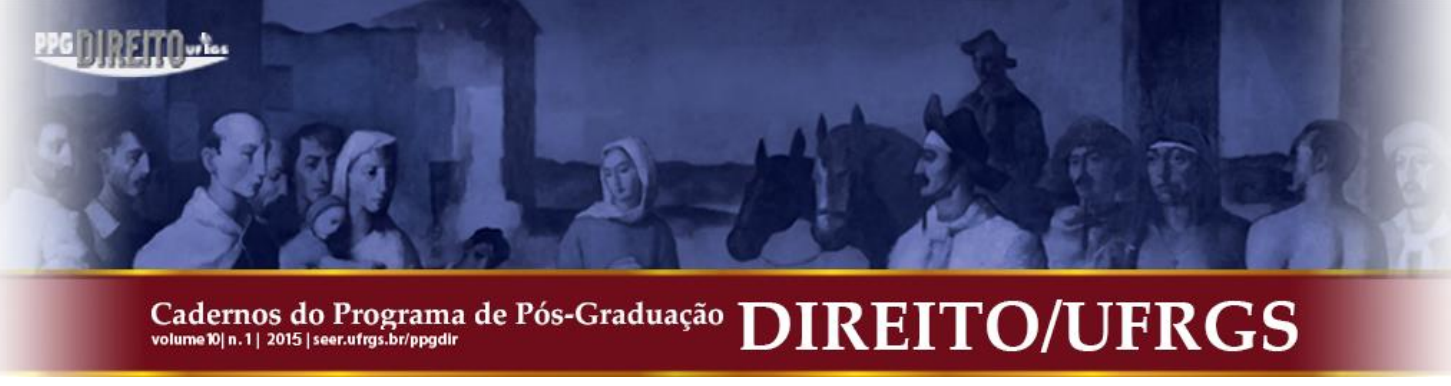

diálogo e auxiliam na busca de soluções, tornando-se atores sociais importantes para o acompanhamento e adimplemento dos acordos restaurativos.

Os benefícios da Justiça Restaurativa são notáveis: auxiliam a vítima a reduzir o medo, insegurança e ressentimento, diminuindo os efeitos traumáticos relacionados à transgressão. De outra parte, oportuniza ao ofensor ouvir o relato do sofrimento causado pela violência, visualizar sua real dimensão e reparar seus danos, promovendo, com isso, sua inclusão social. Nas palavras de Paul Mccold e Ted Wachtel (2003, p. 03): “A capacidade da justiça restaurativa de preencher essas necessidades emocionais e de relacionamento é o ponto chave para a obtenção e manutenção de uma sociedade civil saudável.” Em síntese, a Justiça Restaurativa funciona como um modelo integrador de composição do conflito.

No tocante à violência por razões de gênero, a Justiça Restaurativa opera como um instrumento que pode tirar a pessoa que sofre o conflito da posição de vítima, permitindo seu papel como protagonista. Suas vantagens se tornam ainda mais evidentes diante do empoderamento de todas as partes afetadas pelo conflito.

Em 29 de novembro de 2010, buscando garantir o direito fundamental de acesso à justiça na forma do já aludido artigo 5ำ inciso XXXV, da Constituição Federal, a Resolução $\mathrm{n}^{\mathrm{o}} 125$, do Conselho Nacional de Justiça (CNJ), estabeleceu em seu artigo $1^{\mathrm{o}}$ a "Política Judiciária Nacional de tratamento dos conflitos de interesses, tendente a assegurar a todos o direito à solução dos conflitos por meios adequados à sua natureza e peculiaridade", adotando os processos restaurativos como política pública de solução de conflitos e representando um avanço na prestação jurisdicional com a finalidade precípua de pacificação de conflitos e tensões sociais gerados por violências ou infrações.

A admissão, por parte do CNJ - por intermédio da Emenda n ${ }^{\circ} 01$, de 31/01/2013, na supramencionada Resolução -, de postulados típicos da Justiça Restaurativa no âmbito penal brasileiro como meio de atingir a pacificação social foi, discursivamente, edificante, dispondo que "os processos restaurativos podem incluir a mediação, a conciliação, a reunião familiar ou

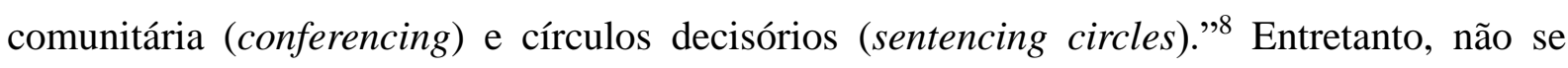
pode olvidar a incoerência da dita Resolução, que, ao invés de privilegiar as práticas da justiça comunitária - descentralização dos serviços jurisdicionais -, concebeu a realização dos círculos restaurativos dentro dos Centros Judiciários de Solução de Conflitos e Cidadania, de

\footnotetext{
${ }^{8}$ Princípio $n^{\circ} 2$ da Resolução no 2002/12, de 24 de julho de 2002, do Conselho Econômico e Social da Organização das Nações Unidas.

Cadernos do Programa de Pós-Graduação em Direito PPGDir./UFRgS | Edição Digital | Porto Alegre | Volume X | Número 1 | 2015 | P.190 - 210
} 


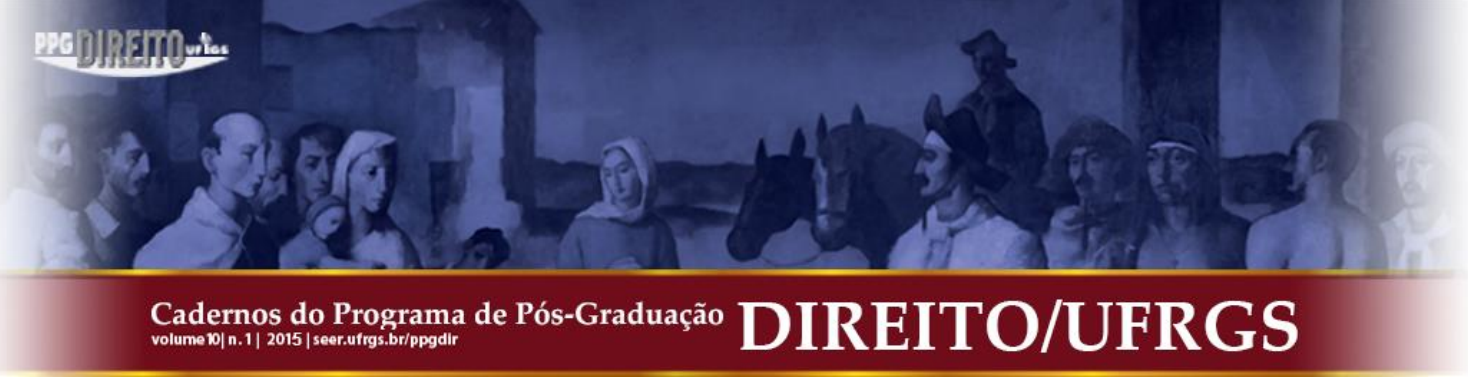

forma que são promovidos por agentes estatais (artigo 12) especialmente formatados para o incremento de estatísticas de prestação jurisdicional. ${ }^{9}$

Em sentido semelhante, Leonardo Sica (2008, p. 11) disserta:

Tanto a transação penal e a conciliação da Lei $\mathrm{n}^{\circ}$ 9.099/1995, como o plea bargaining do Direito anglo-saxão, são exemplos de justiça consensual que não se aplicam à Justiça Restaurativa, muito pelo contrário: esta procura distanciar-se daqueles instrumentos autoritários e/ou burocráticos, que impõem uma "negociação" forçada sob a ameaça de pena e processo, desvinculada de quaisquer preocupações com a restauração da paz jurídica e o restabelecimento da comunicação.

Nota-se que, ao revés do que se propõe em termos de revolução do paradigma estatal monopolizador da justiça pública, o CNJ criou um novo mecanismo relegitimador e promotor de concentração e controle mais aprimorado das atividades jurisdicionais estatais. Destarte, o modelo proposto não merece ser visto como um modelo emancipador das práticas comunitárias de resolução de conflitos, mas, ao contrário, reserva no Poder Judiciário sua coordenação e validação do resultado restaurativo.

À crítica de que a descentralização da Justiça Restaurativa provocaria uma desjudicialização da Justiça Criminal e privatização do Direito Penal, "sujeitando o infrator, e também a vítima, a um controle ilegítimo de pessoas não investidas de autoridade pública" (PINTO, Op. cit., p. 28), é oponível o argumento de que "o processo restaurativo não é exercício privado, mas o exercício comunitário - portanto também público - de uma porção do antes exclusivo monopólio estatal da justiça penal, numa concretização de princípios e regras constitucionais." (PINTO, Op. cit., p. 28). Dessa forma, João Salm e Jackson da Silva Leal (2012, p. 211) ponderam:

\begin{abstract}
Nessa esteira, trabalhando a procedimentalidade adotada por um paradigma de Justiça Restaurativa e Comunitária, necessário trazer um elemento fulcral nesta dinâmica dialogal que se pauta não pelo Direito legislado, mas por topos ou topoi, ou seja, um corpo de valores que sejam comuns e comunitariamente aceitos e que permitam aos indivíduos transitarem em seus discursos, saberes e necessidades de recomposição, não ficando atrelados a uma receita ou procedimentalidade determinada hegemônica e legitimada pela sua oficialidade.
\end{abstract}

O escopo da Justiça Restaurativa é fornecer uma via alternativa dinâmica e pacificadora que prima pela reconstrução do tecido social e comunitário à aplicação de punições aflitivas que multiplicam o sofrimento humano e promovem a cultura do crime.

\footnotetext{
${ }^{9}$ No mesmo sentido, a Lei $\mathrm{n}^{\circ}$ 9.099/95 se apresentou como sendo instauradora do modelo consensual no Brasil, mas, com a prática, centralizou ainda mais os meios de resolução de conflitos intersubjetivos nas entranhas estatais, expandindo demasiadamente o ius puniendi.

Cadernos do Programa de Pós-Graduação em Direito PPGDir./UFRGS | Edição Digital | Porto Alegre | Volume X | Número 1 | 2015 | P.190 - 210
} 


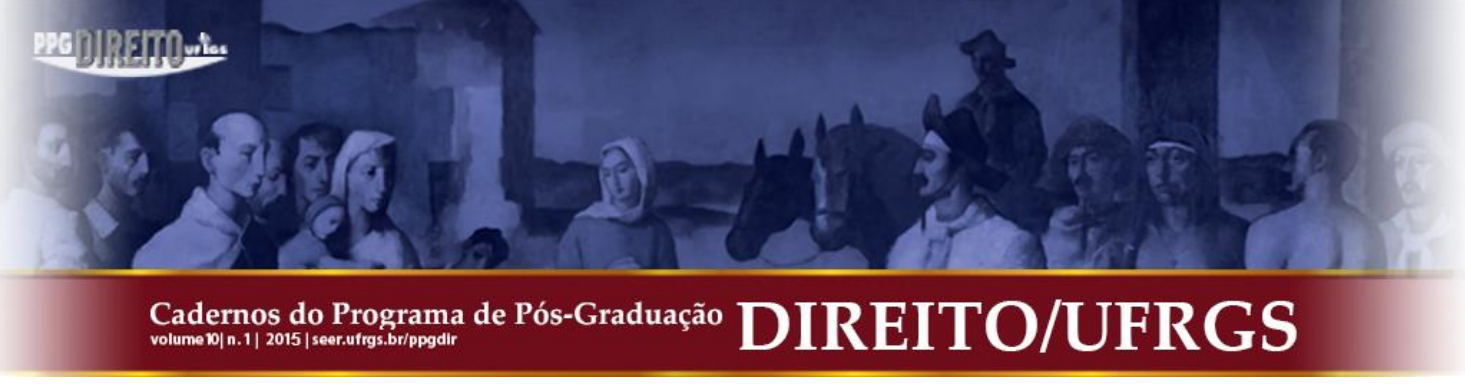

Assim, ela se preocupa em restabelecer as relações interpessoais e não produzir uma verdade artificial, como pretende o sistema processual penal, com vistas a apontar culpados e revitimizar ofendidos. Portanto, a Justiça Restaurativa não pode vir a ser uma continuidade do modelo tradicional, isto é, um instrumento a serviço do sistema criminal.

Com efeito, a despeito da gravidade que envolve o assédio moral - tal como tantas outras formas de violência, mas com uma particular sutileza -, é preciso reconhecer que delegar ao Estado a capacidade postulatória não ensejaria resultados satisfatórios, tanto do ponto de vista da vítima, quando do agressor e da sociedade. Deveras, na seara intrafamiliar, como salienta Carmen Hein de Campos (2010, p. 30): “a decisão que pretende 'reconciliar' a família nega às mulheres a condição de sujeitos de direitos, mantém a subjugação feminina e incentiva a utilização da violência como um sistema de 'ordenação familiar", introjetando o conformismo diante de uma suposta inexorabilidade de relações hierarquizadas.

Entretanto, cabe ressaltar que a justiça restaurativa não defende um ideal de família a ser suportado a todo custo pelas mulheres, como aduz a autora supramencionada à possibilidade de renúncia à representação constante do art. 16 da Lei 11.340/06. Apenas se entende que a "eterna culpa e histórica responsabilidade pela manutenção de famílias aparentemente harmoniosas" (CAMPOS, C., 2010, p. 30) não figuram como um paradigma a ser superado pelo Direito Penal positivado. Nessa esteira, resta claro que a desagregação familiar é promovida, muitas vezes, pela presença da violência.

A Justiça Restaurativa exsurge, então, como uma oportunidade de reconciliação que só será promovida se a vítima participar com vontade livre e consciente (procedimento voluntário e contributivo). Caso contrário, não será possível instaurar o círculo restaurativo, ocasião em que se pode recorrer ao Poder Judiciário (procedimento contencioso e contraditório). ${ }^{10}$ Nesse sentido, Leonardo Sica (Op. cit., p. 10) reitera que a voluntariedade é um requisito básico para a instauração do procedimento restaurativo, de tal forma que o direito ao processo mantém-se intacto. O mesmo autor (Ibid) acrescenta ainda:

Por outro lado, o direito ao processo deve ser concebido como direito, não como obrigação, ou seja: o direito ao processo, para ser pleno e realizável, deve incluir o direito de evitar o processo, naquelas circunstâncias em que a resposta punitiva possa ser substituída por outras reações penais, como a reparação-conciliação, a qual entendemos que só pode ter lugar no espaço extrajudicial e extraprocessual da

\footnotetext{
${ }^{10}$ Mas a aceitação da instauração do procedimento restaurativo extingue o direito de queixa ou representação, em que pese a revogabilidade do acordo restaurativo, de sorte que lhe restará apenas a busca da reparação cível negociada.
} 


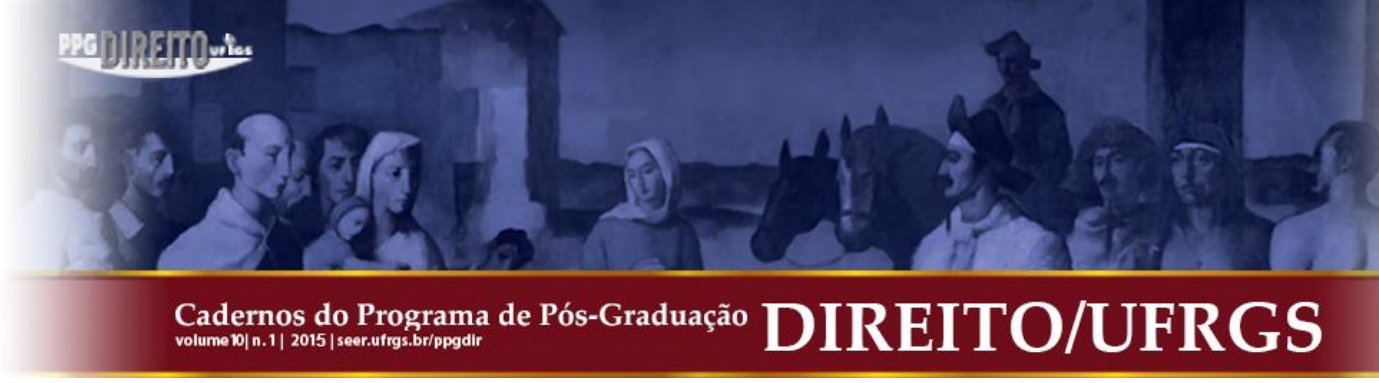

2008.

Disponível

em:

<http://www.scielo.br/scielo.php?pid=S0102-

69092008000100011\&script=sci_arttext $>$. Acesso em: 29 fev. 2012.

FRANÇA, Genival Veloso de. Medicina legal. Rio de Janeiro: Guanabara Koogan, 2004.

HIRIGOYEN, Marie-France. Assédio Moral: a violência perversa no cotidiano. 9. ed. Rio de Janeiro: Bertrand Brasil, 2007.

KARAM, Maria Lúcia. Violência de gênero: o paradoxal entusiasmo pelo rigor penal. Boletim IBCCRIM, São Paulo, v.14, n.168, p. 6-7, nov. 2006.

KUHN, Thomas S. A estrutura das revoluções científicas. 8. ed. São Paulo: Perspectiva, 2003.

LAURENZO COPELLO, Patricia. La violencia de género en la Ley Integral: valoración político-criminal. Revista Electrónica de Ciencia Penal y Criminología (en línea), n. 07-08, p. 08:1-08:23, 2005. Disponível em: <http://criminet.ugr.es/recpc/07/recpc07-08.pdf>. Acesso em: 13 mar. 2012.

MCCOLD, Paul; WACHTEL, Ted. Em Busca de um Paradigma: uma teoria de Justiça Restaurativa. In: CONGRESSO MUNDIAL DE CRIMINOLOGIA, XIII, 2003, Rio de Janeiro. Disponível em: <http://www.iirp.edu/article_detail.php?article_id=NTYy>. Acesso em: 11 abr. 2013.

MUCHEMBLED, Robert. Una historia de la violencia: del final de la edad media a la actualidad. Madrid: Paidós, 2010.

PINTO, Renato Sócrates Gomes. Justiça Restaurativa é Possível no Brasil?. In: SLAKMON, Catherine; VITTO, Renato Campos Pinto de; PINTO, Renato Sócrates Gomes (Org.). Justiça Restaurativa. Brasília: Ministério da Justiça e Programa das Nações Unidas para o Desenvolvimento - PNUD, 2005.

PIRES, Álvaro. A racionalidade penal moderna, o público e os direitos humanos. Novos estudos Cebrap, São Paulo, n. 68, p. 39-60, 2004.

ROVINSKI, Sonia Liane Reichert. Dano Psíquico em Mulheres Vítimas de Violência. Rio de Janeiro: Lumen Juris, 2004. 
